\title{
Leprechaunism: In Vitro Insulin Action Despite Genetic Insulin Resistance ${ }^{1}$
}

\author{
MITCHELL E. GEFFNER, SOLOMON A. KAPLAN, NOELLE BERSCH, BARBARA M. LIPPE, \\ WESLEY G. SMITH, RONALD A. NAGEL, THOMAS V. SANTULLI, JR., CHOH HAO LI, AND \\ DAVID W. GOLDE \\ Department of Pediatrics [M.E.G., S.A.K., B.M.L., W.G.S., R.A.N., T.V.S.J and Department of Medicine [N.B., \\ D.W.G.J, UCLA School of Medicine, Los Angeles 90024 and Laboratory of Molecular Endocrinology [C.H.L.]. \\ University of California, San Francisco, California 94143
}

\begin{abstract}
We recently identified a female leprechaun infant with marked hyperinsulinemia [as high as 10,975 $\mu \mathrm{U} / \mathrm{ml}(78,746 \mathrm{pmol} /$ liter $)$, presumably secondary to insulin resistance. She had two physical findings suggestive of possible insulin action: cystic ovarian enlargement with gonadotropin-independent steroid secretion and persistent, severe myocardial hypertrophy. To examine the pathophysiology of this disorder we measured the in vitro sensitivity to insulin and other growth factors of erythroid progenitors and a T-lymphoblast cell line derived from her peripheral blood. Resistance to insulin was demonstrated by failure of her circulating erythroid progenitor cells to augment proliferation in response to physiologic concentrations of insulin $(1-10 \mathrm{ng} / \mathrm{ml})$. An immortalized T lymphoblast cell line was established by transforming the cells with the human retrovirus human $\mathrm{T}$ cell leukemia virus II. This cell line showed little or no response to physiologic concentrations of insulin contrary to consistently observed stimulation of colony formation by cell lines similarly derived from normals. The patient's 'T lymphoblasts, however, showed normal sensitivity to insulin-like growth factor I. In response to supraphysiologic insulin concentra tions $(25-1000 \mathrm{ng} / \mathrm{ml})$, leprechaun T lymphoblasts showed significant augmentation of colony formation (peak $189 \%$ above baseline at $50 \mathrm{ng} / \mathrm{ml}$ ); normal T lymphoblasts also showed responsiveness at these high insulin concentrations. Preincubation with a monoclonal antibody against the insulin-like growth factor I receptor $(\alpha \mathrm{IR}-3$ at $\mathbf{5 0 0 0}$ $\mathrm{ng} / \mathrm{ml}$ ) blocked the in vitro effect of physiologic concentrations of insulin-like growth factor and supraphysiologic concentrations of insulin on leprechaun and control $T$ lymphoblast colony formation, but had no clear effect upon the response to physiologic insulin concentrations. These findings document genetic insulin resistance in hematopoietic cells from a patient with leprechaunism. Response to supraphysiologic concentrations of insulin appears to be mediated via the insulin-like growth factor receptor mechanism which remains intact. Such action in vivo could account for the ovarian and cardiac findings in the patient. (Pediatr Res 22: 286-291, 1987)
\end{abstract}

Received September 26, 1986; accepted April 8, 1987

Reprints Mitchell E. Geffner, M.D.. UCLA Medical Center. Department of Pediatrics. Los Angeles, C $\wedge 90024$.

Supported in part by Grants RR-865. CA32737, CA 30388, and AM-18677 from the National Institutes of Health, and by a grant from the Diabetes Research and Education Foundation.

'Presented in part at the 1986 meetings of the Society for Pediatric Research [1986 Pediatr Res 20:329a(abstr)].

\author{
Abbreviations \\ BFU-E, erythroid progenitor cells or burst-forming units \\ of the erythroid line \\ HTLV, human T-cell leukemia virus \\ T-LB, T lymphoblast \\ IGF-I, insulin-like growth factor I \\ $\mathrm{LRF}$, luteinizing-hormone releasing factor \\ $\mathrm{LH}$, luteinizing hormone \\ FSH, follicle-stimulating hormone \\ $\mathrm{GH}$, growth hormone \\ GMP, guanosine monophosphate \\ AIB, aminoisobutyric acid \\ EB, Epstein-Barr \\ SI, Système International d'Unités
}

Leprechaunism (Donahue's syndrome) is a rare disorder characterized clinically by intrauterine and postnatal growth retardation, diminished fat and muscle tissue, characteristic facies, precocious puberty, and early death (1). The most common physiologic disturbance in this condition, however, is hyperinsulinism due to severe insulin resistance (2). While leprechaunism has been described in approximately 30 patients, only limited studies of the mechanism of the insulin resistance have been reported (3). Both insulin receptor and postreceptor defects have been proposed to account for the insulin resistance in different patients. Previous investigators have found persistence of the insulin resistance in cultured cells suggesting a primary genetic basis for the reduced insulin sensitivity.

We describe herein a patient with leprechaunism with marked hyperinsulinemia and many of the classical phenotypic features of the leprechaun state. There were two unusual physical findings: large, autonomously functioning, polycystic ovaries and persistent, diffuse, severe myocardial hypertrophy, abnormalities likely to be associated with insulin action. Using clonogenic assays employing both freshly isolated BFU-E (4-9) and HTLVII transformed T-LB cells $(10,11)$, we demonstrated in vitro responses only at supraphysiologic concentrations of added insulin. This activity was completely blocked by pretreatment with antibody to the IGF-I receptor suggesting that the observed insulin action was mediated through the IGF-I receptor. Such a mechanism could account for the ovarian and cardiac findings in this and other leprechaun patients.

\section{CASE REPORT}

The patient was a $1480 \mathrm{~g}, 38 \mathrm{~cm}$ (50th centile for $30 \mathrm{wk}$ gestation) female product of a term gestation born to a $19-y$ r-old 
Filipine female ( $(2, P(), T \wedge B 1)$. The patient's father is black and unrelated to her mother.

At birth, the child was noted to have severe intrauterine growth retardation associated with depleted subcutaneous and muscle tissue. She also had peculiar facies characterized by a depressed nasal bridge, underdeveloped periorbital bony structures. posteriorly rotated and downwardly displaced pinnae with underdeveloped superior helices, a right preauricular skin tag. upturned nares, a very broad upper lip with a very thin vermilion border and underdeveloped philtrum, and a high-arched palate. $A$ short. midsystolic murmur at the the lower left sternal border radiating to the back, protuberant nipples, diffuse hypertrichosis, and a prominent elitoris also were noted. A specific syndrome was not identified at this time. The karyotype was $46 \times X$. Cardiologic evaluation, including echocardiogram. was consistent with diffuse myocardial hypertrophy.

At age 1.25 months, free peritoneal air was noted on a radiograph of the abdomen, but laparotomy failed to reveal any bowel perforation. However, the ovaries were noted to be quite enlarged (maximal diameter was $6-8 \mathrm{~cm}$ on the left and $5-6 \mathrm{~cm}$ on the right) and contained multiple follicular cysts. separated from each other by septa of normal stromal tissue.

At age 3.5 months, the patient first developed intermittent hyperglycemia and hypoglyecmia and the diagnosis of leprechaunism was entertained. $\wedge$ serum insulin level was 2() $44 \mu \mathrm{U} /$ $\mathrm{ml}(14.666 \mathrm{pmol} / \mathrm{liter})$. A simultaneous ('peptide level was 4.5 $\mathrm{ng} / \mathrm{ml}$ ( normal stimulated level $=1.5-9 .() \mathrm{ng} / \mathrm{ml}$ ). Plasma glucose levels ranged between 38 and $144 \mathrm{ng} / \mathrm{dl}(2.09$ and $7.9 .3 \mathrm{mmol} /$ liter). Somatomedin-( was $<0.10 \mathrm{U} / \mathrm{ml}$ (normal for age $(0.17-$ $0.62 \mathrm{~J} / \mathrm{ml}$ ) and glycosvlated hemoglobin was $3.5 \%$ (normal $4-$ $7 \%$ ). Pelvic ultrasound revealed persistenee of bilateral ovarian enlargement $(1.8 \times 1 \times 3 \mathrm{~cm}$ on the right and $2 \mathrm{~cm}$ in greatest diameter on the left) with hoth ovaries containing small cysts. Serum I.II was 5 IU Jiter (normal for age $<2-20$ IU/liter). FSH 2 IU)/liter (normal for age $<2-4$ IU/L.). and estradiol $7 \mathrm{pg} / \mathrm{ml}$ (25.7 pmol/liter: normal for age $<30 \mathrm{pg} / \mathrm{ml}$. $<110 \mathrm{pmol} / \mathrm{liter})$. Persistence of significant diffuse myocardial hypertrophy was noted.

At age 5.5 months bilateral breast development (Tanner III) was noted for the first time without other evidence of estrogen effect. A pelvic ultrasonogram again showed bilaterally enlarged ovaries. Basal $1 . H$ was $2.5 \mathrm{H} /$ /liter. ISSH $<1$ IU/liter. estradiol $180 \mathrm{pg} / \mathrm{ml}(66 \mathrm{pmol} / \mathrm{liter}$, normal for age $<30 \mathrm{pg} / \mathrm{ml} \mathrm{l}<110$ $\mathrm{pmol} /$ liter). estronc $72 \mathrm{pg} / \mathrm{ml}$ (normal for age $<10 \mathrm{pg} / \mathrm{ml}$ ): and testosterone $0.76 \mathrm{ng} / \mathrm{ml}(2.64 \mathrm{nmol} /$ liter: normal for age $<0.10$ $\mathrm{ng} / \mathrm{ml}:<0.35 \mathrm{nmol} / \mathrm{liter})$. Following a $1(0)-\mu \mathrm{g}$ intravenous bolus of $\mathrm{I}$ Rl: there was no significant increase of serum $\mathrm{LH}$ or $\mathrm{F}$ SH concentrations over basal kevels. In an attempt to control the hypoglvecmia which only responded to feeding every $2 \mathrm{~h}$. diat roxide $(5 \mathrm{mg} / \mathrm{kg} /$ day $)$ was begun. The serum insulin level before diazoxide was 10.975 $\mathrm{H} / \mathrm{J} / \mathrm{ml}(78.746 \mathrm{pmol} /$ liter). Hyperglyeemia ensued and responded to omission of diazoxide for $24 \mathrm{~h}$. The diaroxide was resumed and ultimately increased to $10 \mathrm{mg} / \mathrm{kg} /$ day because of the recurrence of hypoglycemia: the serum insulin level $2 \mathrm{wk}$ later was $117 \mu \mathrm{J} / \mathrm{ml}$ (840) pmol/liter). Throughout this time limited growth was noted. Subsequently. the family moved to another state where the baby died at 7 months of age. $\Lambda t$ autopsy, there was a normal-sized pancreas with marked isletcell hyperplasia (immunohistochemical staining positive for insulin), nodular regeneration in the liver. a high-lying hemorrhagic left ovary, an enlarged right ovary, myocardial fibril hypertrophy, cortical brain atrophy, and a 2 ()-cm pineal cyst. Vo specific cause of death was found.

\section{MATIRIAIS ANI) MITHOISS}

Patients. I lematopoietic cells were obtained from the peripheral blood of the leprechaun when she was 4 months old. Control data for the BFU-F: and T lymphoblast cell line experiments were derived from pools of normal adults, including seven males.
12 females, mean age $( \pm \mathrm{SE})=3(0.4 \pm 1.69 \mathrm{vr}$, and normal children including three males four females. including three infants $\leq 4$ months of age (mean age -6.50$) \pm 2.39 \mathrm{vr}$ ). All studies were performed with the approval of the licl t Human Subject Protection Committer and with the informed consent of the parents of the infant with leprechaunism and of all control subjects and/or their parents.

$B F C-E$. Assays for the stimulatory effects of purified hormones on BFU-F. were performed as previously described $(4-.9)$. liwo to $10 \mathrm{ml}$ of venous blood was collected in preservative-free sterile heparin. Buffy coat cells were separated by centrifugation and treated with ammonium chloride-lris buffer at $37^{\circ} \mathrm{C}$ to lyse erythrocytes. The cell pellets were washed once with eomplete medium. Nucleated cells were adjusted or a final concentration of $3 \times 10^{6} / \mathrm{ml}$. and plated at a concentration of $3 \times 10 \% / \mathrm{ml}$ in Falcon flat-bottomed microtiter plates (5). Ien $\mu$ lof either biosunthetic, recombinant human insulin in concentrations of 1.2 . $3.4,5,6,7,8,9,10 \mathrm{ng} / \mathrm{ml}$. synthetic I $(\mathrm{ir}-\mathrm{I}(10.11) \mathrm{in}$ concentrations of $1.2 .3,4.5 .6 .7 .8 .9 .10 \mathrm{ng} / \mathrm{ml}$ or highls purified human ( $\mathrm{sH}$ in concentrations of $10,25,50.100 .200 .500 \mathrm{ng} /$ $\mathrm{ml}$ (4). were added with phosphate-buffered saline (p) 7.4 ). The cells were cultured in methylecllulose at a tinal concentration of 0.8\% (Methocel F.4M premium. Dow (hemical (o). Midland. MI). Iscove's modification of Dulbecco's medium (lovine Scientific. Santa Ana. (A). 30); fetal calf serum (selected lot). 10 " M r $x$-thioglycerol (Calbiochem. I a Jolla. (A), penicillinstreptomycin. and $0.50 \mathrm{l} / \mathrm{ml}$ human urinary erythropoietin (S:). $44 \mathrm{~J} / \mathrm{mg}$ protein: provided by Vational Heart. I ung and Blood Institute), as previously described (6.8). The plates were incubated at $37^{\circ} \mathrm{C}$ in high humidity at $8^{\circ}{ }^{\circ}$ ( $(0)$, in air. After 1()$-14$ davs, large hemoglobinized colonies of ervthroid cells (BF ( I-F) containing at least 5() cells were enumerated using an invorted microscope

T-L.B cell line studies. The methodology for peripheral blood T lomphocyte transformation by the human retrovirus HIT. I II has been described previously (12, 13). I. ow-density peripheral blood mononuclear cells $\left.(5 \times 10)^{5}\right)$. obtaned by ficoll-l lypacpue density-gradient separation. Were cocultivated with an cepual number of lethally irradiated $(10.000$ rad) late-passage Mo cells (11) in Iscove's medium supplemented with 20); fetal bovine serum. The Mo-T eell line was derived from the splecen of a patient with a $T$-cell variant of hairy-cell leukemia (14). A virusinfected immortalized $\mathrm{I}$-cell line is produced in about $t$ wh. Three thousand transformed $\mathrm{T}$-cells/ml were cultured in microtiter plates and hormones were added as above: insulin was added at concentrations of $1-1() \mathrm{ng} / \mathrm{ml}$ as well as 25 . $5(0$. $10(0)$. 250. 500). or $1000 \mathrm{ng} / \mathrm{ml}$. (lonogenic assays of HTl. V-transformed cells were carried out in methyledlulose. Nll cxperiments were performed in duplicate or triplicate. With a maximal replicate variability of $<5 \%$. The unstimulated number of colonies (without added hormone) or baseline level is defined as lon

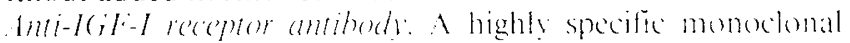
antibody to the IGF-I receptor (oIR-3) was hindty provided by Dr. Steven Jacobs (15.16). Dose-response curves using insutin or IGF-I and the clonogenic bioassal system outlined above. with and without pretreatment with oIR-3. Were generated. Based on previously published data (17), initial concentrations of atR3 tested were 50.250 . 500 . and 500() $\mathrm{ng} / \mathrm{ml}$. When using alR-3. all cells were exposed for $1 \mathrm{~h}$ prior to adding insulin or i il -1

\section{RISLIITS}

BFT-E proliferation. I eprechaun BH:L-I: colony augmentation was tested on one occasion in response to insulin. I( il - I. and growth hormone. I eprechaun BF(J-E; showed no colony augmentation at any added insulin concentration between $1-10$ $\mathrm{ng} / \mathrm{ml}$ (Fig. 1. left). whereas in 42 experiments with adult Bl:L?E. mean peak augmentation was $187 \pm 3.4$ "; ahowe baseline occurring at $8 \mathrm{ng} / \mathrm{ml}$ of added insulin. In 16 experiments with BFU-E: from infants and children. mean peak stimulation was 

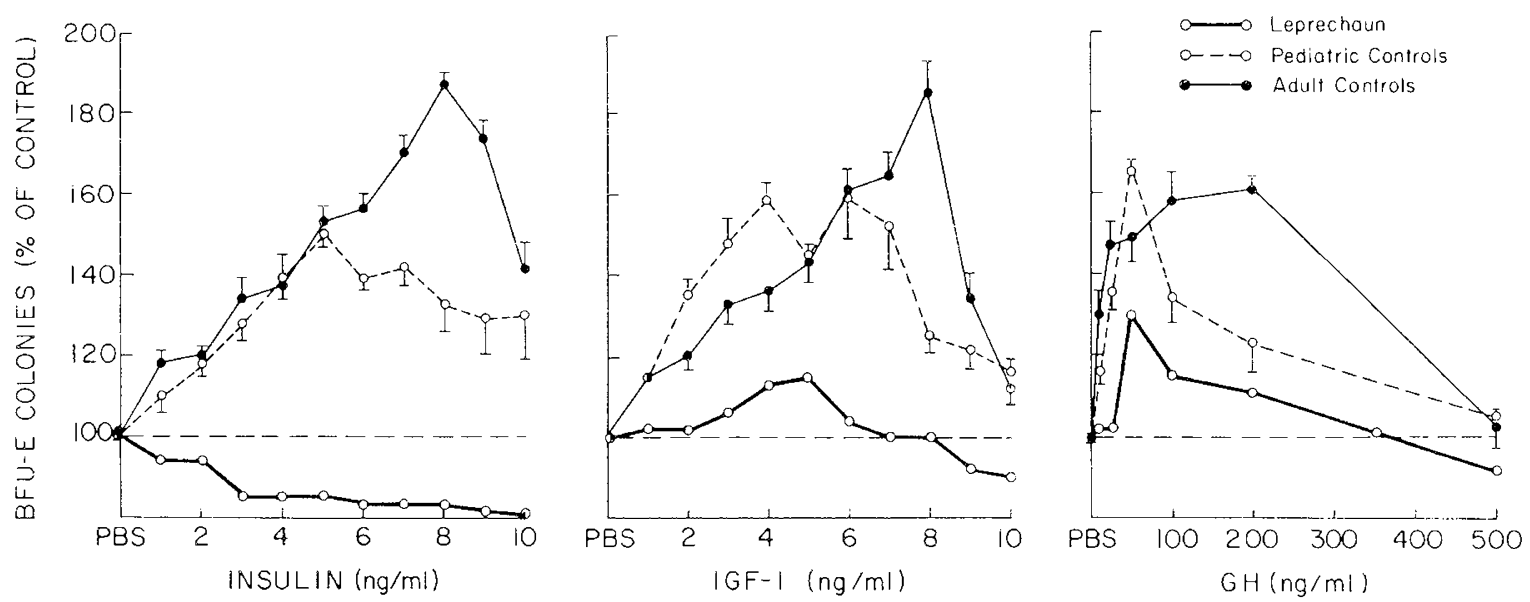

Fig. 1. BFU-E colony formation in response to insulin (left), lGF-1 (center), and GH (right). The y-axis represents colony formation as a percentage of control. The $\mathrm{x}$-axis gives the concentration of added growth factor. To convert insulin (ng/ml) to SI units (pmol/liter), multiply by 179. To convert $\mathrm{GH}(\mathrm{ng} / \mathrm{ml})$ to SI units $(\mu \mathrm{g} / \mathrm{liter})$, multiply by 1.00 .
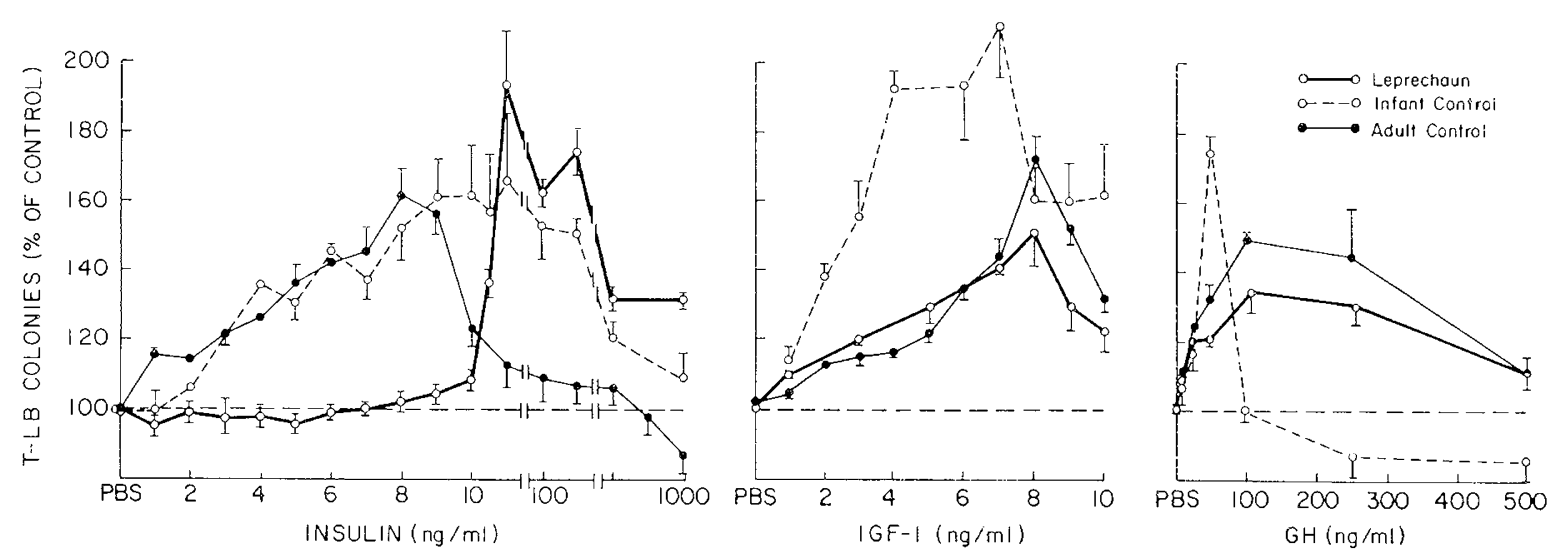

Fig. 2. Colony formation by HTLV-transformed T-cell-line in response to insulin (left), IGF-1 (center), and GH (right). Sensitivity to insulin was evaluated at both low (physiologic) concentrations $[1-10 \mathrm{ng} / \mathrm{ml}$ and high (supraphysiologic) concentrations $(25-1000 \mathrm{ng} / \mathrm{ml})]$.

$150 \pm 2.6 \%$ above baseline occurring at $5 \mathrm{ng} / \mathrm{ml}$ of added insulin. The addition of any insulin caused less proliferation of leprechaun BFU-E than in plates without added insulin, a phenomenon previously observed in some obese subjects (8). Leprechaun BFU-E showed some augmentation of colony formation in response to IGF-I (115\% above baseline) albeit less than either control group (Fig. 1, center); mean peak augmentation in 16 experiments with adult BFU-E was $185 \pm 8.4 \%$ above baseline occurring at $8 \mathrm{ng} / \mathrm{ml}$ of added IGF-I and in 14 experiments with BFU-E from infants and children, mean peak stimulation was $159 \pm 9.8 \%$ above baseline occurring at $6 \mathrm{ng} / \mathrm{ml}$ of added IGFI. Leprechaun BFU-E also showed decreased $\mathrm{GH}$ responsiveness (130\% above baseline) compared to both control groups (Fig. 1, right); in 15 experiments with adult BFU-E, mean peak augmentation was $161 \pm 3.1 \%$ above baseline occurring at $200 \mathrm{ng} / \mathrm{ml}$ of added $\mathrm{GH}$ and in 15 experiments with BFU-E from infants and children, mean peak stimulation was $165 \pm 3.3 \%$ above baseline occurring at $50 \mathrm{ng} / \mathrm{ml}$ of added $\mathrm{GH}$.

Clonogenic stimulation of transformed T-LB. As with the BFUE, leprechaun T-LB (mean of 15 experiments) showed no augmentation of colony formation in response to insulin concentrations up to $9 \mathrm{ng} / \mathrm{ml}$ (Fig. 2, left). Minimal responsiveness was observed at $10 \mathrm{ng} / \mathrm{ml}$. Significant proliferation was consistently seen at concentrations of insulin above $10 \mathrm{ng} / \mathrm{ml}$ with a mean peak augmentation of $193 \pm 15 \%$ above baseline occurring at $50 \mathrm{ng} / \mathrm{ml}$. Control transformed infant T-LB (mean of eight experiments) also showed augmented proliferation of both physiologic and supraphysiologic insulin concentrations. Control adult T-LB showed stimulation as high as $139 \%$ above baseline at $250 \mathrm{ng} / \mathrm{ml}$ of added insulin (in five of 10 experiments). Peak

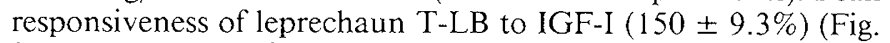
2 , center, mean of 10 experiments) was within two standard deviations of mean responses of control cells (five infant and 7 adult experiments for IGF-I). Peak responsiveness of leprechaun T-LB to GH (133 $\pm 6.7 \%$ ) (Fig. 2, right, mean of eight experiments) was normal compared to adult controls (mean of six experiments) and slightly decreased compared to infant controls (mean of three experiments).

$T-L B$ proliferation after $\alpha I R-3$ pretreatment. No augmentation of either leprechaun or control T-LB colony proliferation was seen in response to $\alpha \mathrm{IR}-3$ alone (at concentrations between 50 $5000 \mathrm{ng} / \mathrm{ml}$, data not shown). Using IGF-I concentrations of $1-$ $10 \mathrm{ng} / \mathrm{ml}, 500 \mathrm{ng} / \mathrm{ml}$ of $\alpha \mathrm{IR}-3$ partially blocked and $5000 \mathrm{ng} / \mathrm{ml}$ totally blocked augmentation of leprechaun (Fig. 3, left) and adult control (Fig. 3, center) T-LB colony formation. Infant control T-LB (Fig. 3, right) showed significantly but not completely blocked colony augmentation in response to $5000 \mathrm{ng} / \mathrm{ml}$ of $\alpha$ IR-3.

To examine whether the augmenting effect of supraphysiologic insulin concentrations upon leprechaun and control T-LB growth might be due to stimulation through the IGF-I receptor, the responsiveness of T-LB was evaluated after pretreatment with $\alpha$ IR-3 (Fig. 4). Since the early peak augmentation of proliferation of T-LB generally occurs at added insulin concentrations of 7-9 $\mathrm{ng} / \mathrm{ml}$ and the late peak between $100-500 \mathrm{ng} / \mathrm{ml}$, the effect of $\alpha$ IR-3 pretreatment was tested at these concentrations of added insulin. Although no concentration of $\alpha$ IR-3 completely blocked the augmenting effect of insulin at $7 \mathrm{ng} / \mathrm{ml}$ of insulin, increasing 


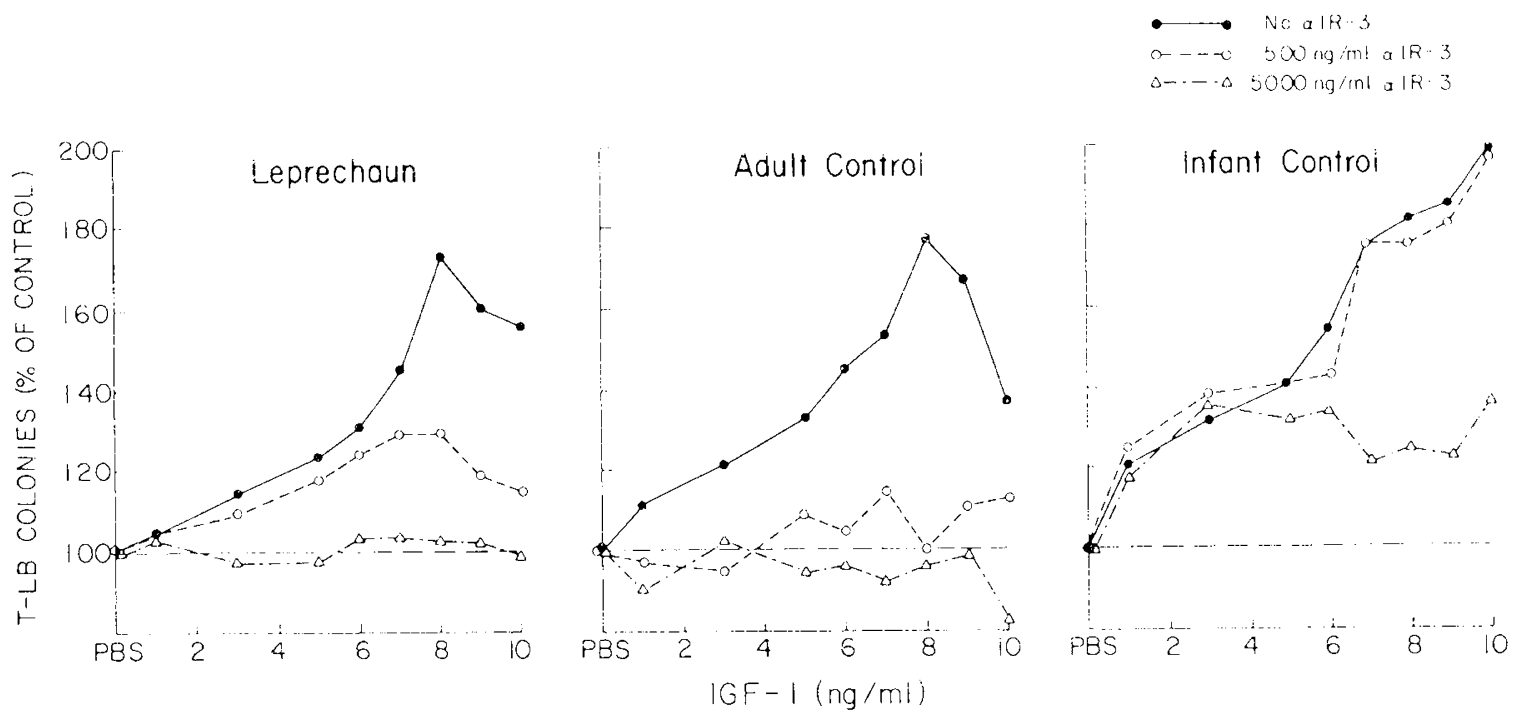

IFig. 3. Feflect of preincubation with aIR-3 on T-I.B colong augmentation in response to IC if - I. The responses of the keprechaun T-I B are shown on the leff. the adult control T-I.B in the center. and the infant control $\mathrm{I}-\mathrm{I}$. B on the righth.
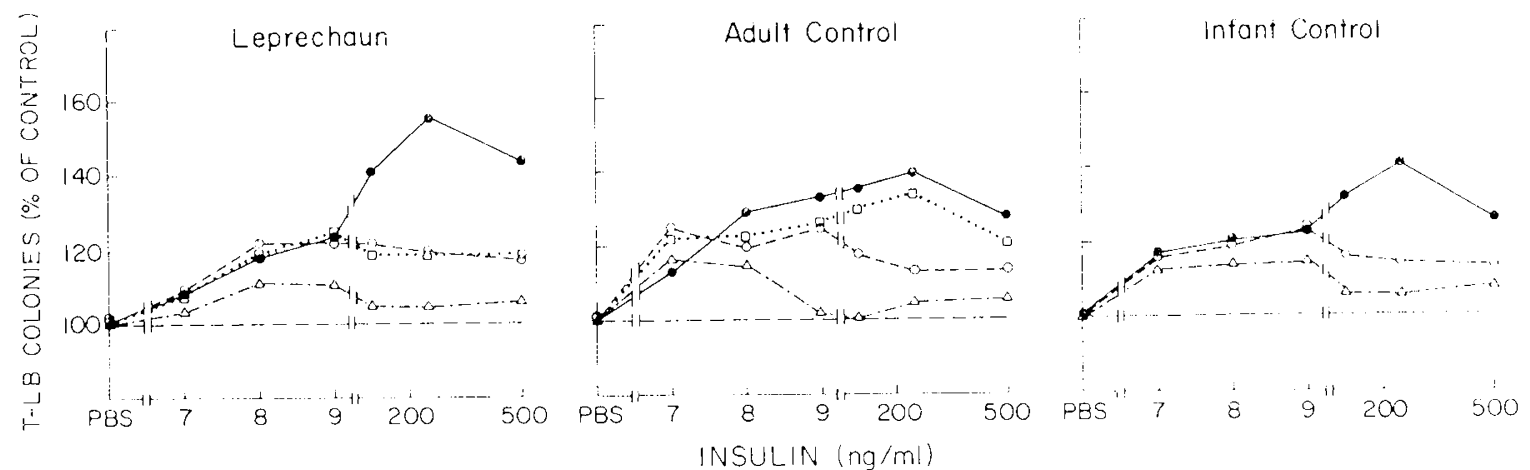

Iig. 4, liffect of preincubation with erlR-3 on T-lymphoblast colony augmentation in response to insulin. The responses of the leprechatun $1-1$.B

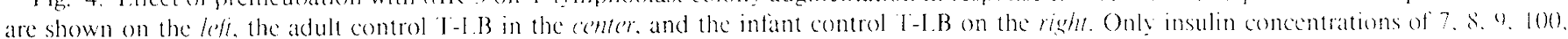
250 , and $500 \mathrm{ng} / \mathrm{ml}$ were used (note breaks in $x$-axis).

concentrations of (xIR-3 began to decrease the proliferative capacity of leprechaun (Fig. 4, lefi). adult control (Fig. 4. ('enter), and infant control (Fig. 4, right ) ' $-\mathrm{I}$. B to all higher added insulin concentrations, with almost complete blockade achieved at an (xIR-3 concentration of $5(0) 0) \mathrm{ng} / \mathrm{ml}$.

\section{IDISCUSSION}

Using in vitro clonogenic bioassays, we have documented nearcomplete resistance to physiologic concentrations of insulin in a newly described leprechaun infant. Absent augmentation of BFU-I: colony formation by insulin could still reflect in vivo environmental influences since the BFU $\mathrm{J}-\mathrm{E}$ represent a primary tissue explant. On the other hand, because the virally transformed T-lymphoblast cell line is many generations removed from the in vivo environment, the significantly blunted response of these cells to physiologic insulin concentrations must reflect genetically programed insulin resistance. The specificity of the insulin resistance is suggested by the presence of normal responsiveness to IGF-I.

Detailed evaluation of the mechanism of the insulin resistance in leprechaunism has been attempted in only four previous patients. The most extensively studied patient, Arkansas I ( Ark1), had variable findings, including normal insulin binding to monocytes and cultured fibroblasts (18), decreased insulin bind- ing to monocytes (19). erythrocytes (20), and cultured fibroblasts (21), and increased binding affinity with decreased sensitivity of binding to alterations in $\mathrm{pH}$ and temperature using $\mathrm{E} B \mathrm{~B}$ - virustransformed B-lymphocites (22. 23). More recently Hlsas of al. (2) reexamined cultured fibroblasts from this patient and found no high-affinity insulin binding and normal low-affinity binding (2).

In contrast. another leprechaun patient. Winnipeg/NIH, was reported to have a $>80{ }^{\circ} \circ$ reduction in instilin binding $t o$ cultured fibroblasts (3. 24). Insulin-stimulated glucose incorporation was markedly blunted. but insulin-mediated methyl-AIB uptake was normal in this patient's fibroblasts. These results were nearly identical when the fibroblasts were exposed to IGF-I. suggesting that this leprechaun had a receptor defect common to the homologous insulin and IGF-I receptors involving coupling of ligand signal for glucose incorporation. but not for methyl-AIB uptake. In a third leprechaun patient. Chapel Hill, there was decreased insulin binding to liver, normal insulin binding to fibroblasts. and blunted fibroblast uptake of both "H-glucose and ${ }^{3} \mathrm{H}-\mathrm{AIB}$ in response to both insulin and IGF-I $(25,26)$.

A fourth leprechaun. Minnesota/NIH, had more than a 9()$^{\prime \prime} \mathrm{C}$ reduction in insulin binding to EB-virus-transformed B-lymphocytes, presumably on the basis of decreased receptor number (27). These findings suggest that the leprechaun state may result from heterogeneous biochemical/molecular defects. While we 
have not yet defined the molecular basis of the insulin resistance in our patient, e.g. binding, transmembrane-signaling, postreceptor defects, etc., there remains near-total insulin resistance at physiologic concentrations implying that the insulin receptor/ effector mechanism is nonfunctional. Unlike the Winnipeg/NIH and Chapel Hill patients, our leprechaun had normal activity of the IGF-I receptor/effector mechanism.

Our findings of significant clonogenic augmentation of T-LB at supraphysiologic concentrations of added insulin, with a dosedependent competitive inhibition of this stimulation by preincubation with the anti-IGF-I-receptor antibody, suggest that insulin action can occur via the IGF-I receptor. The measured serum insulin concentrations in our patient, as high as $459 \mathrm{ng} /$ $\mathrm{ml}(78,746 \mathrm{pmol} /$ liter $)$, were in the range in which insulin significantly augmented in vitro T-LB colony formation (25$1000 \mathrm{ng} / \mathrm{ml} ; 4484-179,375 \mathrm{pmol} / \mathrm{L}$ ). Similarly, Flier et al. (17), using human skin fibroblasts, found that $\alpha \mathrm{IR}-3$ inhibited $\left[{ }^{3} \mathrm{H}\right]$ thymidine incorporation at insulin concentrations $>1000 \mathrm{ng} / \mathrm{ml}$, but not below. These conclusions are consistent with the generally held view that insulin at low (physiologic) concentrations acts in vivo through the insulin receptor predominantly promoting glucose uptake and other metabolic functions, whereas at high concentrations, insulin, acting through the IGF-I receptor, serves as a mitogen, stimulating $\left[{ }^{3} \mathrm{H}\right]$ thymidine uptake, DNA synthesis, and cell replication $(15,17)$.

The unusual clinical findings of persistent, diffuse myocardial hypertrophy and cystic ovaries may be clinical markers of insulin action through the IGF-I receptor. The presence of massive cystic ovarian enlargement and autonomous steroidogenesis (as judged from the flat serum gonadotropin responses on the LRF test) could result from direct insulin action upon the ovary. Fifty percent of previously reported leprechaun infants have had ovarian enlargement, although previously noted precocious puberty in these patients has been attributed to hypothalamic-pituitary hyperfunction despite normal gonadotropin measurements in several patients (1). IGF-I receptors have been described in normal human ovarian tissue (28). In the swine granulosa cell model (29), stimulation with IGF-I results in production of pregnenolone and progesterone. Adashi et al. (30) also have reported that highly purified IGF-I $(50 \mathrm{ng} / \mathrm{ml})$ induced a $93 \%$ increase in $\left[{ }^{35}\right.$ S]sulfate incorporation into extracellular proteoglycans in a primary culture of rat granulosa cells (30). The constellation of ovarian enlargement, cyst formation, and abnormal steroidogenesis has been noted in other patients with resistance to insulin action upon glucose disposal, e.g. thin women with polycystic ovarian disease and no acanthosis nigricans (9), patients with type A insulin resistance (31), and in uremic individuals (32). The ovarian tissue of one obese woman with polycystic ovarian disease, acanthosis, and marked hyperinsulinemia responded in vitro to stimulation by insulin $(500 \mathrm{ng} / \mathrm{ml})$ with production of androstenedione and testosterone (33).

While insulin is known to stimulate myocardial hypertrophy in the infant of the diabetic mother and in the infant with nesidioblastosis (34), the mechanism by which this occurs is unknown. Both insulin and IGF-I receptors have been found in heart and other vascular endothelium $(35,36)$. It is possible that the significant myocardial hypertrophy observed in our patient and in other leprechauns $(1,25,27)$ could result from persistent hyperinsulinemia acting through the IGF-I receptor.

Selective insulin action on some tissues, but not others, in the face of resistance to insulin action on carbohydrate disposal, could be related to the density (and/or affinity) of IGF-I receptors in a given tissue. This concept is supported by the work of D'Ercole et al. (37) who have shown the highest specific binding of ${ }^{125} \mathrm{I}$-somatomedin-C $(12.5 \%)$ to membranes derived from adult pig ovarian tissue compared to all other pig tissues examined. Lack of response by muscle and fat tissue of the leprechaun could reflect limited IGF-I binding to these tissues. Using rat tissue membranes, D'Ercole et al. (37) found low specific binding $(4.7 \%)$ to muscle tissue and no specific binding to adipocytes.
Skottner et al. (38) have also noted that human fat cells do not possess IGF-I receptors. Thus, the presence or absence of IGF-I receptors may ultimately determine whether and where the growth-promoting actions of insulin can occur in insulin-resistant states.

\section{REFERENCES}

1. Rosenberg AM, Haworth JC, Degroot W, Trevenen CL, Rechler MM 1980 A case of leprechaunism with severe hyperinsulinemia. Am $\mathbf{J}$ Dis Child 134:170-175

2. Elsas LJ, Endo F, Strumlauf E, Elders J, Priest JH 1985 Leprechaunism: an inherited defect in a high-affinity insulin receptor. Am J Hum Genet 37:7388

3. Rechler MM 1982 Leprechaunism and related syndromes with primary insulin resistance: heterogeneity of molecular defects. In: Sheppard JR, Anderson VE, Eaton JW (eds) Membranes and Genetic Discases. Alan R. Liss, Inc, New York, pp 245-281

4. Golde DW, Bersch N, Kaplan SA, Rimoin DL, Li CH 1980 Peripheral unresponsiveness to human growth hormone in Laron dwarfism. N Engl J Med 303:1156-1159

5. Ashcraft MW, Hartzband PI, Van Herle AJ, Bersch N, Golde DW 1983 A unique growth factor in patients with acromegaloidism. J Clin Endocrinol Metab 57:272-276

6. Bersch N. Groopman JE. Golde DW 1982 Natural and biosynthetic insulin stimulates the growth of human erythroid progenitors in vitro. $\mathrm{J}$ Clin Endocrinol Metab 55:1209-1211

7. Golde DW, Bersch N, Li CH 1977 Growth hormone: species-specific stimulation of erythropoiesis in vitro. Science 196:1112-1113

8. Geffner ME, Kaplan SA, Bersch N, Lippe BM, Scott ML, Bergman RN, Golde DW 1985 Diminished in vitro responsiveness of circulating erythroid progenitor cells to insulin as an indicator of insulin resistance. J Clin Endocrinol Metab 60:103-108

9. Geffner ME, Kaplan SA, Bersch N, Golde DW, Landaw EM, Chang RJ 1986 Persistence of insulin resistance in polycystic ovarian discase after inhibition of ovarian steroid secretion. Fertil Steril 45:327-333

10. Li CH, Yamashiro D, Gospodarowicz D, Kaplan SL, Van Vliet G 1983 Total synthesis of insulin-like growth factor I (somatomedin C). Proc Natl Acad Sci USA 80:2216-2220

11. Van Wyk JJ, Russell WE. Li CH 1984 Synthetic somatomedin C: comparison with natural hormone isolated from human plasma. Proc Natl Acad Sci USA 81:740-742

12. Chen ISY, Quan SG, Golde D 1983 Human T-cell leukemia virus type II transforms normal human lymphocytes. Proc Natl Acad Sci USA 80:70067009

13. Chen ISY, McLaughlin J, Gasson JC, Clark SC. Golde DW 1983 Molecular characterization of genome of a novel human $\mathrm{T}$-cell leukemia virus. Nature 305:502-505

14. Saxon A. Stevens RH, Golde DW 1978 T-lymphocyte variant of hairy cell leukemia. Ann Intern Med 88:323-326

15. Van Wyk JJ, Graves DC, Casella SJ, Jacobs S 1985 Evidence from monoclonal antibody studies that insulin stimulates deoxyribonucleic acid synthesis through the type I somatomedin receptor. J Clin Endocrinol Metab 61:639643

16. Kull FC, Jacobs S. Su Y-F, Svoboda ME, Van Wyk JJ. Cuatrecasas P 1983 Monoclonal antibodies to receptors for insulin and somatomedin-C. J Biol Chem 258:6561-6566

17. Flier JS, Usher P, Moses AC 1986 Monoclonal antibody to the type I insulinlike growth factor (IGF-1) receptor blocks IGF-I receptor-mediated D.VA synthesis: clarification of the mitogenic mechanisms of IGF-I and insulin in human skin fibroblasts. Proc Natl Acad Sci USA 83:664-668

18. Kobayashi M, Olefsky JM, Elders J, Mako ME, Given BD. Schedewic HK Fiser RH, Hintz RL, Horner JA, Rubinstein AH 1978 Insulin resistance due to a defect distal to the insulin receptor: demonstration in a patient with leprechaunism. Proc Natl Acad Sci USA 75:3469-3473

19. Taylor SI, Marcus-Samuels B. Ryan-Young J, Leventhal S. Elders MJ 1986 Genetics of the insulin receptor defect in a patient with extreme insulin resistance. J Clin Endocrinol Metab 62:1130-1135

20. Elders MJ. Hill DE, Schedewie HK. Herzberg V, Boughter M. Taylor SI 1982 Characterization of the erythrocyte insulin receptor in leprechaunism. Clin Res 30:897a(abstr)

21. Craig JW, Larner J, Locker EF, Widom B, Elders MJ 1984 Mechanisms of insulin resistance in cultured fibroblasts from a patient with leprechaunism: impaired post-binding actions of insulin and multiplication-stimulating activity. Metabolism 33:1084-1096

22. Taylor SI, Roth J, Blizzard RM, Elders MJ 1981 Qualitative abnormalities in insulin binding in a patient with extreme insulin resistance: decreased sensitivity to alterations in temperature and pH. Proc Natl Acad Sci USA 78:7157-7161

23. Taylor SI, Hedo JA, Underhill LH, Kasuga M. Elders MJ, Roth J 1982 Extreme insulin resistance in association with abnormally high binding affinity of insulin receptors from a patient with leprechaunism: evidence for a defect intrinsic to the receptor. J Clin Endocrinol Metab 55:1108-1113

24. Schilling EE, Rechler MM, Grunfeld C, Rosenberg AM 1979 Primary defect of insulin receptors in skin fibroblasts cultured from an infant with leprechaunism and insulin resistance. Proc Natl Acad Sci USA 76:5877-5881 
25. 1) Fircole A.J. Inderwood 1.1. (iroclke I. Plet A 1979 1.eprechaunism: studic of the relaternshe anong hyprinsulinism insulin resistance and growth retardation. I ( lin Indecrinol Metab $48: 495.502$

26. Kaplowile IPB. D Frolc A.J 1982 libroblasts from a pation with keprechaunism are resistant wo insulin. epidermal growth factor. and somatomedin ( I I ( lin lindocrinol Mctab 55:741 748

27. Taylor S1 Samuels B, Roth J Kasuga M. Hodo IA (iorden P. Brasel 1) E: Pokora I. Fongel RR 1982 I)ecreased insulin binding in cultured lymphocytes from two patients with extreme insulin resistance. I (lin bindocrinol Metal $54: 919-930$

28. Baver S Scibel M (iates (; Moses A. Hier I Io86 ldentification of insulinlike growth factor receptors in human granulosa cells. Scicntitic Program and Abstracts for the 3.3rd Anmual Mecting of the Socicty for (iy necologic Investigation. 76 fabstr

29. Veldhuis JI). Furlancto $\mathrm{RW} 1985$ frophic actions of human somatomedin (Cinsulin-like growth fietor I on ovarian cells: in vitro studies with swine granulosa cells \& (lin Indocrinol Metah) | 16:1235-1242

30) Adashif:Y Resnick ( $\mathrm{F}$ S Soboda Ml Van Wh JJ. Hascall V('. Yanagishita $M$ 1986, Independent and synergistic actions of somatomedin-( $i$ in the stimulation of prokeoglycan biosynthesis by cultured rat granulosa cells lindocrinologe $118.450-458$

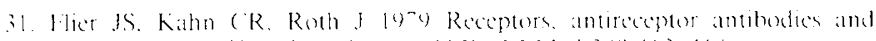
mechanisms of insulin resistance. $\backslash$ Engl I Med $3(x)+1: 419$

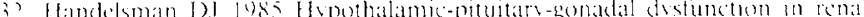

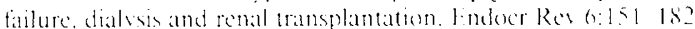

3. Bamberi RI Makris A. Ran K.I lyst Insulin stimulates androgen acomu-

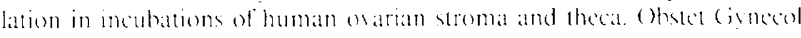
$64: 3.5805$

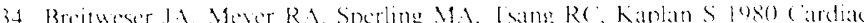

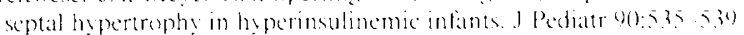

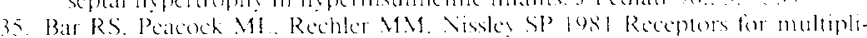
cation-stimulating activits on human anterial and venous endothelial cells. I (lin Endocrinol Melat 52:s14.816

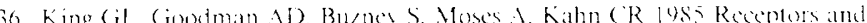
growth-promoting offects of insulin and insulinlike growth factors on coll from bovine retinal capillaries and aorta. I ( lin Invest $75: 10$ ) 8 . 10.30

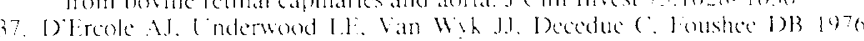
Specificits. topography. and ontegem of the somatemedin-( receptor in mammalian ussues In: Pecile A Multer lEl feds) (irowth Hormone and Related Peptides. Facorota Medical. Amsterdam. pp $19(0) 201$

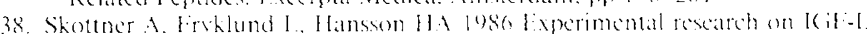
Acta Pedate Scand [Suppl] i25:107-111 